У $\triangle \mathrm{K} 330.34$

\title{
EVOLUTION OF ENVIRONMENTAL MANAGEMENT CONCEPTS IN TERMS OF GLOBAL ENVIRONMENTAL CHALLENGES
}

\author{
Elena Dovgal \\ Doctor of Economic Sciences, Professor, \\ V. N. Karazin Kharkiv National University, \\ 6, Svobody sq., Kharkiv, Ukraine, 61022, \\ e-mail: e.dovgal@karazin.ua \\ ORCID: https://orcid.org/0000-0003-3219-9731 \\ Irina Panova \\ Senior lecturer, \\ V. N. Karazin Kharkiv National University, \\ 6, Svobody sq., Kharkiv, Ukraine, 61022, \\ e-mail: iryna.panova@karazin.ua \\ ORCID https://orcid.org/0000-0002-1975-5644
}

\begin{abstract}
The relevance of the study is due to the fact that the economic development of civilization in the 21st century is accompanied by numerous environmental and social challenges that scientists around the world are constantly working on. Technogenic and natural disasters that occur on the planet are associated with climate change, which in turn, a significant number of researchers and world leaders believe is a consequence of economic activity. The subject of research of the article is the concept of sustainable development, which actually includes these three aspects: economic, social and environmental. The goal is the evolution of the concepts of nature use in the context of global environmental challenges and their practical use in countries around the world. The objective is to research the concept of sustainable ecologically balanced development of the national economy.

General scientific methods are used, such as system analysis. The following results were obtained: the transition to sustainable development has led to the emergence of numerous concepts of its implementation in the area of addressing sustainable use of natural resources. The theoretical substantiation of such in terms of the laws of thermodynamics is simply impossible, as well as the invention of "perpetual motion". However, the use of inexhaustible energy sources (such as thermonuclear, solar, geothermal, tidal, etc.) and renewable biological resources (transgenic, cloning, etc.) allows us to talk about the possibility of theoretical justification for sustainable ecologically balanced development. At the same time, relative, since this nature use is possible only within use) of the limits of balance in profit and expenditure (reproduction natural resources).

Conclusions: implementation of sustainable development is possible only in the form of sustainable eco-balanced development based on rapidly renewable biological resources and the use of practically inexhaustible energy sources, as well as the use of high technologies. Such development can provide a solution to economic, social and environmental problems with the preservation of the natural complex.
\end{abstract}

Keywords: concepts of natural use, global environmental challenges, the concept of sustainable development, sustainable ecologically balanced development, the preservation of the natural complex.

1. Introduction. The economic growth of civilization in the $21^{\text {st }}$ century comes amid numerous environmental and social challenges, which scientists all over the world are trying to solve. The urgency of these challenges arises from their cross-disciplinary nature. In fact, although the pace of global economic growth is fairly moderate, it is often asymmetrical and seriously disbalanced. Thus, the gap between developed and developing countries is getting deeper, which in turn leads to the escalation of social problems. Environmental problems of the entire continents remain unsolved. In particular, lack of food and drinking water has brought some African countries on the verge of disaster and starvation. On the other hand, such countries as China and India, enjoying a high rate of economic growth, face serious problems with environmental deterioration. Manmade and natural disasters that happen on the planet are believed to contribute to the climate change, which, in turn, a significant number of researchers and world leaders consider to result from economic activities.
2. Statement of the Research Problem. In today's global scientific theory and practice there are some examples of a positive economic growth achieved by certain countries, which have managed to find a reasonable balance between ensuring economic development and preserving natural environment. Awareness of the clear threat of environmental disaster has catalyzed the process of joining efforts to develop the strategies of such a development that will help to reverse dangerous trends and allow adopting fundamentally different standards of human life and activities including doing business. Moreover, on the international scale, particularly in the United Nations and other supranational organizations, the Concept of Sustainable Development was scientifically designed and adopted by the world political leaders in 1992. This Concept encompasses the three aspects: economic, social and environmental.

The origins of this concept can be traced back to the 1970s, when researches by local and foreign researchers were published. However, the theoretical grounds of environmental management in terms of global 
environmental challenges are not yet developed enough to enable its practical use either in developed or developing countries.

3. The aim of the study. The aim of this article is to analyze evolution of environmental management concepts in terms of global environmental challenges and their practical use in countries across the world.

4. Substantial statement of the problem. The theory underlying the development of environmental management concepts in terms of global environmental challenges was provided by the works of such neoclassicists as Eugen von Böhm-Bawerk, Léon Walras, and Alfred Marshall. Unlike representatives of classical economics, they argued that economic growth leads to ecosystem disruption while a balanced use of natural resources is its fundamental prerequisite [1].

Awareness of how important the coordination of economic and social processes as well as environmental protection are resulted in the introduction of the innovative economic theory of sustainable development by Herman Daly [2].

In his publication "Beyond Growth" (1996) H. Daly outlined the basic principles of the economic theory of sustainable development. In that regard he wrote that one of the ways to nullify the content of any concept is expanding it to the extent of making it overinclusive. With that he emphasizes the importance of giving clear definitions because "adoption of a term that exceedingly lacks definition creates a situation when the one who succeds in defining the term automatically wins a great political battle for influencing our future" [2].

In terms of economic growth stages the postindustrial society has replaced the industrial one having shifted the emphasis from developing material wealth to producing knowledge and information, using renewable sources of energy, and protecting environment instead of resources and means of labour. According to D. Bell [3], the main controversy inherent to postindustrial society is a serious gap in the knowledge level between teachers, scientists, and researchers on the one hand, and undereducated people on the other hand.

To overcome this controversy the Concept of Sustainable Development was adopted, which was to harmonize its economic, social, and environmental aspects. Overall, the majority of researchers regard the theory of sustainable development as the most prominent in over twenty-five years. The greater part of developed countries across the world use it to work out their own strategies of development. These strategies define the programs aimed at minimizing the long-lasting environmental effects of economic growth. Fro example, resources are planned to be used in such a way that will ensure future generations do not suffer from their scarcity and exhaustion. The analysis of the researches by foreign scientists has enabled developing the strategies of resource utilization and regeneration in terms of global environmental challenges.
Overall, with reference to a long-term period of economic growth it is usually true to say that "what is ecological is economical". There can be distinguished approximately six criteria of sustainable economic development determining the vision of natural resource regeneration:

1. The supplies of renewable natural resources are not to decrease in the long run, i.e. it is necessary to establish the scheme for simple regeneration.

2. Maximum possible slowdown in the depletion of non-renewable natural resource supplies with the perspective of their replacement with other unlimited types of resources.

3. A possibility to minimize waste based on the implementation of low-waste resource-saving technologies.

4. Environmental pollution (both total and specific types) is not to exceed its present level in the long run. A possibility to minimize pollution to socially and economically acceptable level (a "zero" level of pollution can not be achieved).

5. The use of innovative eco-technologies to reduce atmosphere, land, and water pollution, namely the maximum use of means enabling the slowdown of this harmful process.

6. Introduction of investment projects to reduce the level of ecosystem pollution [4].

With reference to this, it is necessary to emphasize the importance of people's consumption behavior. The move towards sustainable development mainly means implementing reasonable restrictions in goods and services consumption, unlike industrial development that encourages maximum consumption as a prerequisite for further prosperity.

Rapid advancement in science and technology has enabled humanity to satisfy basic people's needs in the course of economic growth while on the other hand, it has caused serious damage to their living conditions, which has in turn catalyzed a rise in environmental awareness. In general the emergence of the "environmentally-friendly economic growth" concepts, such as "green", "blue", "eco-intensive", "low-carbon", and "circular" economy could be expected. These concepts radically alter global business practices shifting focus to solving environmental problems. A number of countries across the world are now undergoing this change, moving towards a new industrial model (industry 4.0) based on the use of methods and technologies that minimize negative impact on the environment.

It is commonly known that intensification of anthropogenic activity has endangered the survival of humanity due to the depletion of many natural resources and environmental deterioration. In Ukraine, the urgency of the need to solve these problems is aggravated by a long-term lack of economic growth and insufficient state control over the compliance with environmental regulations. Namely, finding a solution to environmental and economic problems as well as balancing environmental management in the national economy 
became the focus of research by leading Ukrainian scientists.

V. Vernadsky was the first to develop a comprehensive doctrine of "the noosphere" (the sphere of cognition) as a completely new phase in the evolution of biosphere emerging as a result of interaction between nature and society under the influence of the creative activity of man, which transforms the world [5].

V. Vernadsky associates biosphere with a living being, which is transformed into the noosphere, where the key factor of development is human cognition. The structural unit of the noosphere is "neobiogeocoenosis", which is a limited, intrinsically homogeneous, functional system of interrelated living organisms and the environment under the influence of production. The constituents of neobiogeocoenosis are ecotope (atmosphere, hydrosphere, and lithosphere), biocoenosis (plant and animal life), and noocoenosis (society, means and products of labour). While ecotope and biocoenosis determine the productive activity of man, noocoenosis is concerned with the environmental system of national economy.

This theory was further elaborated in the concept of a hierarchical biosphere structure and its properties by L. Melnick. There can be distinguished the following properties of a hierarchical biosphere structure: self-organization (self-maintenance of exchange processes between society and environment), homeostasis (dynamic equilibrium of eco-economic processes), self-regulation (essential amendments to the mechanisms of eco-economic regulation), self-development (enhancement of the factors of national eco-economic system improvement) [6].

In 1970s a special interest was generated by the future-oriented theories (technocratic, liberal and radical, optimistic and pessimistic), which generally represent the forecasts of building an "environmentally balanced" national economy and regard the interaction between society and nature in terms of solving a dilemma: economic growth versus environmental security.

In 1980s a close attention was paid to the elaboration of alternative social development models on the basis of the theories regarding a qualitatively new economic growth as a means of solving environmental problems. These theories are characterized by a scientific interpretation and justification of environmental imperatives of socioeconomic development, definition of factors, forms, and methods of eco-economic control, as well as including environmental attributes in the mechanisms of economic regulation.

In 1990s the theory of sustainable environmentally balanced development of national economy was introduced. The term "sustainable development" refers to the process of harmonizing production forces, satisfying the needs of all community members provided that environmental integrity is ensured and gradually restored, creating opportunities for balancing its potential with the requirements of national economic entities.

The concept of sustainable environmentally balanced development involves defining environmentally oriented approaches to the macroeconomic analysis. Among economically adjusted criteria, we find it reasonable to use a socalled "green" GNI produced without violating environmental standards and regulations, public environmental spending, and per capita environmental spending.

GNI produced without violating environmental standards and regulations (GNI) is defined as a difference between the total GNI and its changing due to the qualitative deterioration of the environment ( $\triangle$ GNIe) $[4]$ :

$$
\mathrm{GNI}^{\prime}=\mathrm{GNI}-\Delta \mathrm{GNIe}
$$

Public environmental spending (Sp) should include spending on environmental management necessary to restore the process of human activities (Sr), the use of natural resources included in fixed and working assets (Sn), protection and timely rehabilitation of the environment (Spr), carrying out fundamental and applied research work in the field of environmental protection and reasonable use of natural resources (Se) [4]:

$$
\mathrm{Sp}=\mathrm{Sr}+\mathrm{Sn}+\mathrm{Spr}+\mathrm{Se}
$$

Within the concept of sustainable environmentally balanced development of national economy the basic constituent of national wealth is considered to be natural capital viewed not only as natural resources supplies but also as assets producing natural goods and environmental services that can be provided only by integral undamaged structurally varied ecosystems. There can be distinguished the following types of natural capital:

- renewable (biological);

- non-renewable (geological);

- hybrid (modified as a result of purposeful intervention by man) [4].

Exhaustion of natural regeneration potential and the degree of environmental deterioration are calculated using the "ecosystem quantity" and "ecosystem quality" indices. Ecosystem quantity is calculated as a change in the area of species in the territory of Ukraine, while ecosystem quality shows a change in the abundance of national biodiversity in the current and base years. Natural capital index (Inc) is calculated as a product of aggregated indices of ecosystem quantity (Ieqn) and ecosystem quality (Ieql) [4]:

$$
\text { Inc }=\text { Ieqn } \bullet \text { Ieql }
$$

Environmentally oriented approach to the evaluation of business activities and overall national economy is based on the idea that economic growth must not damage the integrity of biological and physical natural systems, their sustainability and the 
global stability of the entire biosphere. It means implementing environmentally oriented methods of measuring the economic activity of countries, which will allow evaluating their environmental policy.

However, the concept of environmentally oriented measuring has not yet been sufficiently studied, and different authors interpret it in different ways. Nevertheless, the majority of them are inclined to viewing it as a complex multifaceted phenomenon. Some researchers use index approach to define environmentally oriented measuring of economic growth. Thus, analyses of this concept focus considerably on the index of environmentally oriented measuring, which is defined as a system capability to protect the environment.

As was already mentioned, the "measuring" concept is interpreted as: 1) determining a physical value with special technical means; 2) measuring in the process of experimental search for these values. Alternatively, S. I. Dorohuntsov et al. [7, p. 19] regard measuring as an operation used to determine ratio of one measured quantity to the other, which is taken as 1 , that is a number showing this ratio is called a numerical value of a measured quantity.

Thus, measuring the sustainability of economic growth is to show the level of ensuring biological and economic systems integrity, their capability to maintain themselves and adapt instead of deteriorating and suffer destruction. From everything mentioned above environmentally oriented measuring is closest to determining the status of a process or system. As environmentally oriented measuring is one of the criteria used to evaluate sustainable economic development, it has to be economically justified.

Environmentally oriented measuring of national economic growth can be regarded as a quantitative evaluation of environmental policy in the three areas:

- ecosystem preservation using the indicators of air, biodiversity, and land condition, quantity and quality of water, radiation and environmental hazards;

- environmental pressure using the indicators of atmosphere pollution, ecosystem load, particularly water pollution load, waste production and lack of its utilization;

- determination of indicators showing the contribution of countries, local communities, and business organizations to environmental projects, including international ones.

It should be noted that unsustainable economic activity with reference to environment objectively visualizes in the three interrelated forms: environmental pollution, depletion of natural resources, and demise of ecosystems.

Determining the range of environmentally oriented measuring of economic growth involves increasing production and distribution costs, which exacerbates the problem of harmonizing the effect of economic and environmental factors. This problem can be solved by joining the four different approaches:

\section{- technological}

(development

of environmentally-friendly technologies, introduction of low-waste production, upgrading of fixed assets);

- development and improvement of the economic mechanism of environmental protection (fines for emitting harmful substances, introduction of additional benefits for producing eco-friendly output);

- implementation of administrative action in case of environmental management regulations violation;

- harmonization of ecological structure (education, guidance, promotion) [8, p. 95].

In appropriate attitude to environmental problems, minimization of financial resources, unawareness of the importance of solving problems arising in business activities have a negative impact on the environment and lead to substantial financial loss.

Conversely, system coordination and balancing all constituents is a crucially important and difficult task, as integration of social and environmental spheres brings about the need for maintaining equal rights of present and future generations in regard to using natural resources. The interaction of social and economic factors requires fair evaluation in the process of material wealth distribution among people of different social level. Thus, consistency of conservational and economic factors requires monetary evaluation of the technological environmental impact. Namely, fulfilling these tasks is one of the main challenges of today's world for many countries and reputable international organizations.

At present, there are several aspects of environmentally sustainable development of national economy:

- a set of all types of human activity aimed at the "perpetual" use of natural resources to satisfy people's needs;

- study of all spheres of human activity (preservation, production, consumption, etc.) in the process of long-term satisfaction of material and spiritual needs of the society;

- $\quad$ scientific justification of the use of various natural environment components and natural resource systems in socio-economic development of the territory of a region, country, or planet;

- justification and feasibility study of the use of natural resources and natural environment components in the short and long run on the basis of IT solutions for managerial decision-making;

- comprehensive cross-disciplinary approach aimed at environmental education for the implementation of sustainable development concept [9].

In the process of production, natural resource management is environmentally sustainable as long as it ensures adequate standards of living, prevents potential damage to the environment, and reasonably controls the exploitation of natural resources. 
Sustainable development involves the balance of economic and social development on the one hand, as well as nature and resources study and protection on the other hand. Thus, it means organizing an economy, which can provide for the removal of conflicts between the growth of productive forces and environmental health. This can be achieved on condition of complying with the law of internal dynamic equilibrium and the principle of environmental management optimality. In this case, environmental management encompasses the whole system of natural environment and resources, this system being interrelated with population and public production recovery at different stages of sociohistorical development.

Sustainable development of national economy can be achieved on the basis of the use of renewable biological resources balances. The use of balance studies enables justification of quota arrangement, which means steady extraction of biological resources that is to be adjusted in accordance with variable characteristics of natural environment.

As early as 1997, the Cabinet of Ministers of Ukraine adopted the Concept of the sustainable development of Ukraine, the fundamentals of which being as follows:

- shift from resource-intensive and environmentally destructive to resource efficient and environmentally-friendly reproduction type;

- primacy of ecology over economy, of ecological criteria, factors, and requirements over economic ones;

- optimal combination of branch and territorial administration of natural resources management and environmental protection, delegation of responsibility for solving eco-economic problems to local authorities and government bodies with central authorities preserving their supervisory function over business entities' compliance with environmental restrictions, standards, and regulations;

- tight control over compliance with environmental legislation, which is to encompass all types and forms of human life and activities, as well as efficient use of state, market, and civil governance levers to regulate eco-economic processes;

- radical economic restructuring and implementation of privatization programs with the account of environmental factors and conforming to the requirements of environmental safety and compliance;

- environmentally oriented science and technology, investment, and innovation policies including clearly defined nationwide priorities concerning steady economic development and a rise in the level of state environmental safety [10].

Alongside evolution of the sustainable economic development concept, we can observe the establishment of environmental economy. The concept of environmental national economy is based on the acknowledgement of the key role of man in the biosphere. It is the conscious activity of man that is meant to ensure essential biocoenosis recovery, and also coevolutionary manner of nature-society interaction.

A move to sustainable development has given rise to numerous concepts concerning its implementation in terms of solving the problems of sustainable environmental management. The theoretical justification of something of the kind from the perspective of the laws of thermodynamics is merely impossible, as is the invention of a "perpetual-motion machine". However, the use of non-depletable energy sources (such as thermonuclear, solar, geothermal, tidal, etc.) and renewable biological resources (transgenic organisms, cloning, etc.) allows mentioning a possibility of theoretical justification in regard to sustainable development. At the same time, this refers to relative sustainable development, as this type of environmental management is possible only within the balance between inputs and outputs (regeneration - utilization) of natural resources.

5. Conclusions and future work. Thus, implementation of sustainable development is possible only in the form of a steady environmentally balanced development based on rapidly renewable biological resources and use of practically nondepletable energy sources, as well as application of high-end technologies. Such type of development will be able to ensure solving economic, social, and environmental problems along with preserving the Earth's natural system.

Research in this field is becoming especially important for theoretical justification of the sustainable development at large. Simultaneously, this research has an impressive applied significance, especially for the development of environmental management strategies, making optimal managerial decisions and their justification, evaluation of natural resources potential and territory environmental condition.

Further development of the concept of sustainable development and national economy greening involves defining priorities in harmonization of eco-economic relations both on the macro- and mega-levels of economy management, because efficient national ecoeconomic policy can be designed only as a result of consistent and focused actions aimed at environmental improvement by the entire global community.

\section{ЕВОЛЮЦІЯ КОНЦЕПЦІЙ ПРИРОДОКОРИСТУВАННЯ В КОНТЕКСТІ ГЛОБАЛЬНИХ ЕКОЛОГІЧНИХ ВИКЛИКІВ}

\footnotetext{
Довгаль Олена Андріївна, докт. екон. наук., професор, Харківський національний університет імені В. Н. Каразіна, м. Свободи, 6, м. Харків, Україна, 61022, e-mail: e.dovgal@karazin.ua, ORCID: https://orcid.org/0000-0003-3219-9731

Панова Ірина Олексіївна, викладач, Харківський національний університет імені В. Н. Каразіна, м. Свободи, 6, м. Харків, Україна, 61022, e-mail: iryna.panova@karazin.ua, ORCID: https://orcid.org/0000-0002-1975-5644
} 
Актуальність дослідження пояснюється тим, що економічний розвиток цивілізації у XXI столітті супроводжується численними екологічними та соціальними викликами, над розв'язанням яких постійно працюють науковці світу. Техногенні та природні катаклізми, що відбуваються на планеті, пов'язують із зміною клімату, яку, в свою чергу, значна кількість дослідників та світових лідерів вважає наслідком економічної діяльності. Предметом дослідження статті є концепція сталого розвитку, яка фрактично включає в себе ці три аспекти: економічний, соціальний та екологічний. Метою статті є еволюція концепцій природокористування в контексті глобальних екологічних викликів та їх практичне використання в країнах світу. Об'єкт полягає в дослідженні концепції сталого еколого-збалансованого розвитку національної економіки.

В якості загальних наукових методів використовуються системний аналіз, а також логічний та історичний методи дослідження. В результаті дослідження були отримані наступні результати: перехід до сталого розвитку зумовив появу численних концепцій його реалізації в площині вирішення питань сталого природокористування. Теоретичне обґрунтування подібного з точки зору законів термодинаміки просто неможливо, як і винахід «вічного двигуна». Однак використання невичерпних джерел енергії (таких як термоядерна, сонячна, геотермальна, приливо-відливна та інші) і поновлюваних біологічних ресурсів (трансгенні, клонування та інші) дозволяє говорити про можливість теоретичного обґрунтування сталого еколого-збалансованого розвитку.

Висновки: реалізація сталого розвитку можлива лише у вигляді стійкого еколого-збалансованого розвитку, заснованого на швидко поновлюваних біологічних ресурсах і використанні практично невичерпних джерел енергії, а також застосуванні наукомістких технологій. Такий розвиток зможе забезпечити вирішення економічних, соціальних та екологічних проблем зі збереженням природного комплексу.

Ключові слова: концепції природокористування, глобальні екологічні виклики, концепція сталого розвитку, стійкий екологозбалансований розвиток, збереження природного комплексу.

\section{ЭВОЛЮЦИЯ КОНЦЕПЦИЙ ПРИРОДОПОЛЬЗОВАНИЯ В КОНТЕКСТЕ ГЛОБАЛЬНЫХ ЭКОЛОГИЧЕСКИХ ВЫЗОВОВ}

Довгаль Елена Андреевна, докт. экон. наук, профессор Харьковский национальный университет имени В. Н. Каразина, пл. Свободы, 6, г. Харьков, Украина, 61022, e-mail: e.dovgal@karazin.ua, ORCID https://orcid.org/0000-0003-3219-9731

Панова Ирина Алексеевна, преподаватель, Харьковский национальный университет имени В. Н. Каразина, пл. Свободы, 6 , г. Харьков, Украина, 61022, e-mail: iryna.panova@karazin.ua, ORCID https://orcid.org/0000-0002-1975-5644

Актуальность исследования объясняется тем, что экономическое развитие цивилизации в XXI веке сопровождается многочисленными экологическими и социальными вызовами, над решением которых постоянно работают ученые мира. Техногенные и природные катаклизмы, происходящие на планете, связывают с изменением климата, которую, в свою очередь, значительное количество исследователей и мировых лидеров считает следствием экономической деятельности. Предметом исследования статьи является концепция устойчивого развития, которая фактически включает в себя эти три аспекта: экономический, социальный и экологический. Целью статьи является эволюция концепций природопользования в контексте глобальных экологических вызовов и их практическое использование в странах мира. Объект состоит в исследовании концепции устойчивого эколого-сбалансированного развития национальной экономики.

В качестве общих научных методов используются системный анализ, а также логический и исторический методы исследования. В результате исследования были получены следующие результаты: переход к устойчивому развитию обусловил появление многочисленных концепций его реализации в плоскости решения вопросов устойчивого природопользования. Теоретическое обоснование подобного с точки зрения законов термодинамики просто невозможно, как и изобретение «вечного двигателя». Однако использование неисчерпаемых источников энергии (таких как термоядерная, солнечная, геотермальная, приливо-отливная и другие) и возобновляемых биологических ресурсов (трансгенных, клонирование и другие) позволяет говорить о возможности теоретического обоснования устойчивого экологосбалансированного развития.

Выводы: реализация устойчивого развития возможна только в виде устойчивого эколого-сбалансированного развития, основанного на быстро возобновляемых биологических ресурсах и использовании практически неисчерпаемых источников энергии, а также применении наукоемких технологий. Такое развитие сможет обеспечить решение экономических, социальных и экологических проблем с сохранением природного комплекса.

Ключевые слова: концепции природопользования, глобальные экологические вызовы, концепция устойчивого развития, устойчивое экологически сбалансированное развитие, сохранение природного комплекса.

\section{References}

1. Bjoler, D. (2007). Ideja ta obov'jazkovistj vidpovidaljnosti za majbutnje. Filosofsjka dumka, 1, 2, 3, 117-134, 77-95, $81-99$. [in Ukrainian]

2. Dejli, Gh. (2002). Poza zrostannjam. Ekonomichna teorija stalogho rozvytku. K.: Intelsfera. [in Ukrainian]

3. Bell, D. (2004). Gryadushchee postindustrialnoe obshchestvo. Opyt sotsialnogo prognozirovaniya (2oe izd.). M.: Akademiya. [in Russian]

4. Danilov-Danilyan, V. I., \& Losev, K. S. (2000). Ekologicheskiy vyzov $i$ ustoychivoe razvitie. M.: ProgressTraditsiya. [in Russian]

5. Vernadskiy, V. I. (1988). Nauchna mysl kak planetnoe yavlenie. M.: Nauka. [in Russian]

6. Meljnyk, L. Gh. (2006). Ekologhichna ekonomika : pidruchnyk. Sumy: Universytetsjka knygha. [in Ukrainian]

7. Doroghuncov, S. I., Pitjurenko, Ju. I., \& Olijnyk, Ja. B. (2000). Rozmishhennja produktyvnykh syl Ukrajiny : navch.-metod. posibnyk dlja samost. vyvch. dysc. K. : KNEU. [in Ukrainian]

8. Nadosha, O. V. (2011). Teoretyko-metodologhichnyj analiz stalogho rozvytku u konteksti suchasnykh doslidnycjkykh pidkhodiv. Derzhavne upravlinnja: udoskonalennja ta rozvytok, 10 . Vzjato z http://www.dy.nayka.com.ua/?op $=1 \& z=341$ (data zvernennja 14.09.2018). [in Ukrainian]

9. International Organization For Standardization. (2018). Environmental Management Systems-Specification With Guidance For Use. Retrieved from https://www.iso.org/standard/23142.html (data zvernennja 10.10.2018).

10. Ekologhija ta socialjnyj zakhyst. (2018). Proghrama Stalyj rozvytok. Vzjato http://www.esz.org.ua/?page_id=2998 (data zvernennja 10.10.2018). [in Ukrainian] 